\title{
PENGARUH TERAPI BERMAIN TERHADAP KECEMASAN ANAK YANG MENGALAMI HOSPITALISASI DI RUANG MIRAH DELIMA RUMAH SAKIT WILLIAM BOOTH SURABAYA Hale, M.A*, Tjahjono**
}

\author{
Sekolah Tinggi Ilmu Kesehatan William Booth \\ Jln Cimanuk No. 20 Surabaya
}

\begin{abstract}
ABSTRAK
Hospitalisasi merupakan penyebab stress bagi anak terutama perpisahan dengan lingkungan keluarga. Kecemasan adalah perasaan yang dialami oleh anak yang timbul akibat hospitalisasi, biasanya dimunculkan dengan anak menangis dan takut pada orang baru. Bermain merupakan terapi yang dilakukan pada anak yang menjalani hospitalisasi, dimana metode ini dapat mengurangi konflik dan kecemasan yang dialami anak. Pada saat bermain anak akan mampu mengekspresikan perasaan frustasi, permusuhan, serta rasa marah, sehingga anak dapat melupakan ketegangan dan mampu beradaptasi terhadap kecemasan. Penelitian ini bertujuan untuk mengetahui pengaruh terapi bermain terhadap kecemasan anak yang menjalani hospitalisasi.Variabel independen adalah terapi bermain dan variabel dependennya adalah kecemasan.Desain penelitian menggunakan pendekatan one group pra-post test design dengan jumlah sampel 27 responden.Data penelitian diambil dengan memberikan kuesioner kepada responden, setelah terkumpul data dianalisa dengan Uji Wilcoxon.Hasil penelitian diperoleh sebagian besar responden berjenis kelamin laki-laki sebanyak 18 responden (67\%), sebagian besar responden belum pernah dirawat di rumah sakit sebanyak 19 responden $(71 \%)$, sebagian responden berusia 6 tahun sebanyak 14 responden $(52 \%)$, responden terbanyak sebelum diberikan terapi bermain memiliki tingkat kecemasan Oversensitivity sebanyak 15 responden $(55 \%)$ dan setelah diberikan terapi bermain didapatkan 13 orang mengalami perubahan/penurunan skor/skala. Berdasarkan uji statistik terdapat pengaruh terapi bermain dengan kecemasan, dengan tingkat kesignifikansinya 0,000 dimana $\rho<0,05$. Hal ini menunjukkan bahwa terapi bermain di rumah sakit tidak hanya akan memberikan rasa senang pada anak, tetapi juga akan membantu anak mengekspresikan perasaan dan pikiran cemas, takut, sedih, tegang, nyeri dan anak akan lebih kooperatif terhadap tindakan keperawatan yang diberikan sehingga diharapkan dapat mempercepat proses penyembuhan.

Kata Kunci: Terapi bermain, Kecemasan, Hospitalisasi
\end{abstract}

\begin{abstract}
Hospitalization is a cause of stress for children, especially parting with the family environment. Anxiety is a feeling experienced by the child arising from hospitalization, usually raised with crying and afraid of new people. Playing therapy is performed in children who undergo hospitalization, where this method can reduce conflict and anxiety experienced by children. At the time of playing children will be able to express feelings of frustration, hostility, and anger, so that children can forget the tension and able to adapt to anxiety. This study aims to determine the effect of play therapy for children who undergo anxiety. Independent variable is playing therapy and the dependent variable is anxiety. Research design approach with in one group pre-post test design with a sample of 27 responden.Data were taken by questionnaire to respondents, after the collected data is analyzed with the Wilcoxon test. The results obtained by the majority of respondents male sex as much as 18 respondents (67\%), the majority of respondents had never been hospitalized many as 19 respondents (71\%), the majority of respondents aged 6 years as many as 14 respondents (52\%), respondents most prior therapy anxiety levels oversensitivity play as many as 15 respondents (55\%) and after the play therapy found 13 people to change / decrease in scores /
\end{abstract}


scale. Based on statistical tests are influences play therapy with anxiety, with 0,000 kesignifikansinya level where $\rho<0.05$.This indicates that play therapy in the hospital will not only give pleasure to the children, but also will help the child to express feelings and thoughts of anxiety, fear, sadness, tension, pain and the child will be more cooperative given to nursing actions that are expected to accelerate healing process.

Keywords: Playing therapy, Anxiety, Hospitalization

\section{Pendahuluan}

Dunia anak adalah dunia bermain, khususnya bagi anak yang berusia dibawah 5 tahun. Bermain bagi anak akan mengembangkan berbagai kemampuan seperti kemampuan motorik dimana anak cepat untuk bergerak, berlari dan melakukan berbagai kegiatan fisik lainnya. Hospitalisasi adalah penyebab stress bagi anak, terutama disebabkan oleh perpisahan dari lingkungan. Perawatan dirumah sakit atau hospitalisasi juga membuat anak kehilangan kontrol terhadap dirinya. Anak yang sakit hampir selalu memperlihatkan sikap yang sangat mudah tersinggung, mudah cemas, pemarah, agresif, penakut, curiga dan sensitif (Hurlock,1999). Kecemasan merupakan perasaan yang paling umum yang dialami oleh pasien anak yang mengalami hospitalisasi. Kecemasan yang sering dialami seperti menangis, dan takut pada orang baru. Respon kecemasan anak tergantung dari tahapan usia anak. Menurut Wright (1995), dalam Naviati (2011), yang meneliti tentang efek hospitalisasi pada perilaku anak menyebutkan bahwa reaksi anak pada hospitalisasi secara garis besar adalah sedih, takut dan bersalah karena menghadapi sesuatu yang belum pernahdialaminya sebelumnya, rasa tidak aman, rasa tidak nyaman, perasaan kehilangan sesuatu yang biasa dialami dan sesuatu yang dirasakan menyakitkan. Berdasarkan penelitian yang dilakukan oleh Coyne (2006) dalam Apriliawati (2011), menjelaskan bahwa anak yang dihospitalisasi mengalami kecemasan dan kegelisahan karena perpisahan dengan orang tua dan keluarga, prosedur pemeriksaan dan pengobatan, dan akibat berada di lingkungan asing. Kecemasan akibat perpisahan pada hospitalisasi anak juga didukung oleh penelitian yang dilakukan oleh Folley (2000), dalam Apriliawati (2011). Penelitian ini menggambarkan bahwa perpisahan dengan orang tua merupakan aspek yang paling menimbulkan stress dan menimbulkan efek bagi anak dan orang tua. Orang tua harus beradaptasi terkait perannya sebagai orang tua dengan anak sakit dan stress yang dialami akibat hospitalisasi pada anak akan mengakibatkan anak merasa takut danvcemas. Kortisol adalah mediator utama respon terhadap stress yang berpartisipasi dalam banyak interaksi antara HPA axis dengan inflamasi yang dimediasi imunologis, sehingga menghambat akumulasi dan fungsi limfosit, monosit/makrofag, oesonofil, dan neutrophil pada daerah inflamasi. Anak yang mengalami stres akan terjadi peningkatan kortisol, yang mana kortisol tersebut akan menghambat pembentukkan antibodi, menurunkan sel darah putih dan imunitas tubuh. Adanya penekanan sistem imun inilah nampaknya akan berakibat pada penghambatan proses penyembuhan. Sehingga memerlukan waktu perawatan yang lebih lama dan bahkan akan mempercepat terjadinya komplikasi-komplikasi selama perawatan. Bermain merupakan terapi pada anak yang menjalani hospitalisasi (Wong, 2008). Saat anak mengalami sakit dan mereka akan terpaksa berpisah dari lingkungan yang dirasakannya aman, penuh kasih sayang, dan menyenangkan yaitu rumah, permainan dan teman sepermainannya. Kebutuhan bermain tidak berhenti selama anak sakit dan harus dirawat di rumah sakit. Sehingga perlu dilakukan terapi bermain.Karena dengan terapi bermain anak-akan lebih rileks dan kooperatif sehingga dapat mempercepat proses penyembuhan.

Kondisi sakit pada anak sangat memungkinkan anak membutuhkan pelayanan kesehatan dirumah sakit. Di Amerika Serikat, diperkirakan lebih dari 5 juta anak menjalani hospitalisasi karena prosedur pembedahan dan lebih dari 50\% dari jumlah tersebut, anak mengalami kecemasan dan stres (Kain,dkk. 2006). Di Indonesia diperkirakan 35 per 1000 anak 
menjalani hospitalisasi (Purwandari, 2009). Dalam jurnal Suparto, pada tahun 2002 di RSUD Dr. Soetomo Surabaya tentang perilaku anak sakit menunjukkan bahwa $70 \%$ pasien pada awalnya menunjukan perilaku yang negatif (agresif maupun depresif) dengan tidak melihat jenis diagnosanya. Sedangkan menurut data dari RS William Booth Surabaya jumlah anak sakit selama 3 bulan terakhir yaitu bulan Juli sampai September 2013 adalah 302 orang. Di Ruang Mirah Delima Rumah Sakit William Booth Surabaya tidak diterapkan terapi bermain pada anak yang mengalami hospitalisasi. Sehingga anak yang dirawat selalu menunjukkan respon kecemasannya. Perawat anak-anak sakit selama dirawat di rumah sakit atau hospitalisasi menimbulkan krisis kecemasan tersendiri bagi anak dan keluarganya. Di rumah sakit, anak harus menghadapi lingkungan yang asing dan pemberian asuhan yang tidak dikenal. Seringkali anak harus berhadapan dengan prosedur yang menimbulkan nyeri, kehilangan kemandirian, dan berbagai hal yang tidak diketahui (Hockenbery\& Wilson, 2009).

Rawat inap atau hospitalisasi pada pasien anak dapat menyebabkan kecemasan dan stres pada semua tingkat manusia. Penyebab dari kecemasan dipengaruhi oleh banyak faktor dari petugas (perawat, dokter dan tenaga kesehatan lainnya), lingkungan baru maupun keluarga yang mendampingi selama perawatan. Keluarga atau orang tua sering merasa cemas dengan perkembangan dan pengobatan anaknya. Kecemasan yang terjadi pada anak dapat memperlambat proses penyembuhan, menurunkan semangat untuk sembuh dan tidak kooperatif terhadap tindakan perawatan yang diberikan (Supartini, 2004). Hal tersebut menyebabkan waktu perawatan yang lebih lama, bahkan akan mempercepat terjadinya komplikasi selama perawatan (Nursalam, 2005). Oleh karena itu perlu adanya penatalaksanaan untuk mengurangi kecemasan pada anak yang menjalani hospitalisasi. Penatalaksanaannya yaitu dengan relaksasi, terapi musik, aktivitas fisik, terapi seni dan terapi bermain. Melalui bermain anak dapat menunjukan apa yang dirasakannya selama hospitalisasi karena dengan melakukan permainan anak dapat melupakan rasa sakitnya (Wong, 2008). Permainan yang terapeutik dapat memperbaiki gangguan emosional dan penurunan kondisi selama dirawat di rumah sakit. Anak-anak membutuhkan bermain, tetapi tidak semua permainan memilki sifat terapeutik. Permainan terapeutik hendaknya disesuaikan dengan usia dan tahapan perkembangan anak (Mahon, 2009). Menurut Subardiah (2009), permainan terapeutik berpengaruh terhadap penurunan kecemasan, kehilangan kontrol, dan ketakutan pada anak yang dirawat di rumah sakit.

Pemberian terapi bermain dapat menurunkan kecemasan pada anak sehingga dapat meningkatkan sikap kooperatif anak selama menjalani hospitalisasi. Dengan terapi bermain anak juga akan memperoleh kegembiraan dan kesenangan sehingga membuat anak lebih kooperatif terhadap tindakan keperawatan yang akan diberikan selama anak menjalani hospitalisasi. Perawat perlu mengupayakan agar perkembangan anak bisa tetap berjalan dengan optimal selama hospitalisasi, selain berupaya untuk mengurangi kecemasan pada anak. Misalnya dengan melaksanakan program terapi bermain. Dengan mengenali masalah kecemasan akibat hospitalisasi. Penulis tertarik untuk melakukan penelitian mengenai cara atau terapi yang tepat untuk menurunkan kecemasan pada anak akibat hospitalisasi. Terapi bermain merupakan cara atau terapi yang akan digunakan penulis dalam mengatasi kecemasan pada anak. Jenis-jenis terapi bermain yang dapat digunakan dalam mengatasi kecemasan pada anak akibat hospitalisasi yaitu permainan boneka atau mobil-mobilan, bercerita, mewarnai dan menggambar. Karena dengan bermain anak dapat membebaskan diri dari tekanan dan kecemasan akibat situasi lingkungan baru atau hospitalisasi.

\section{Metode}

Peneliti menggunakan desain penelitian praeksperimen dengan pendekatan one group pre-post test design. Populasi dalam penelitian ini adalah semua anak yang mengalami kecemasan di ruang anak Mirah Delima Rumah Sakit William Booth Surabaya, adapun sampelnya berjumlah 27 responden. Teknik sampling menggunakan non-probability sampling dengan pendekatan 
purposive sampling. Instrumen penelitian yang digunakan dalam penelitian ini menggunakan alat ukur kecemasan berupa kuesioner kecemasan yaitu RCMAS (The Revised Children's Manifest Anxiety Scale). Data kemudian dianalisa secara univariat dan bivariat dengan uji Wilcoxon.

\section{Hasil dan Pembahasan \\ Hasil}

Data umum ini menggambarkan tentang karakteristik responden berdasarkan jenis kelamin, dirawat dirumah sakit, umur, sedangkan data khusus meliputi derajad kecemasan sebelum dan sesudah pemberian terapi bermain.

Tabel 1 Distribusi frekuensi responden berdasarkan jenis kelamin di Ruang Mirah Delima Rumah Sakit William Booth Surabaya April 2014

\begin{tabular}{|l|c|c|}
\hline JenisKelamin & Frekuensi & Prosentase \\
\hline Laki-laki & 18 & $67 \%$ \\
\hline Perempuan & 9 & $33 \%$ \\
\hline Total & 27 & $100 \%$ \\
\hline
\end{tabular}

Berdasarkan tabel 1 didapatkan sebagian besar responden berjenis kelamin laki-laki sebanyak 18 responden (67\%).

Tabel 2 Distribusi frekuensi responden berdasarkan dirawat dirumah sakit di Ruang Mirah Delima Rumah Sakit William Booth Surabaya April 2014

\begin{tabular}{|l|c|c|}
\hline $\begin{array}{c}\text { Dirawat di } \\
\text { RumahSakit }\end{array}$ & Frekuensi & Prosentase \\
\hline Belum pernah & 19 & $71 \%$ \\
\hline Sudah pernah & 8 & $29 \%$ \\
\hline Total & 27 & $100 \%$ \\
\hline
\end{tabular}

Berdasarkan tabel 2 didapatkan sebagian besar responden belum pernah dirawat di Rumah Sakit sebanyak 19 responden $(71 \%)$.

Tabel 3. Distribusi frekuensi responden berdasarkan umur di Ruang Mirah Delima
Rumah Sakit William Booth Surabaya April 2014

\begin{tabular}{|l|c|c|}
\hline \multicolumn{1}{|c|}{ Umur } & Frekuensi & Prosentase \\
\hline 6 Tahun & 14 & $52 \%$ \\
\hline 7 Tahun & 13 & $48 \%$ \\
\hline Total & 27 & $100 \%$ \\
\hline
\end{tabular}

Berdasarkan tabel 3 didapatkan sebagian responden berusia 6 tahun sebanyak 14 responden $(52 \%)$.

Tabel 4. Derajat kecemasan responden sebelum pemberian terapi bermain April 2014 di Ruang Mirah Delima Rumah Sakit William Booth Surabaya

\begin{tabular}{|l|c|c|}
\hline \multicolumn{1}{|c|}{$\begin{array}{c}\text { Derajat } \\
\text { Kecemasan }\end{array}$} & Frekuensi & $\begin{array}{c}\text { Prosentas } \\
\text { e }\end{array}$ \\
\hline Fisiologis & 5 & $19 \%$ \\
\hline Oversensitivity & 15 & $55 \%$ \\
\hline $\begin{array}{l}\text { Concentration } \\
\text { Anxiety }\end{array}$ & 7 & $26 \%$ \\
\hline Total & 27 & $100 \%$ \\
\hline
\end{tabular}

Berdasarkan tabel diatas didapatkan responden terbanyak sebelum diberikan terapi bermain memiliki tingkat kecemasan Oversensitivity sebanyak 15 responden $(55 \%)$. 
Tabel 5. Distribusi frekwensi responden berdasarkan berubah/tidakberubahnya skala kecemasan RCMAS sesudah pemberian terapi bermain pada tanggal April 2014 di Ruang Mirah Delima Rumah Sakit William Booth Surabaya

\begin{tabular}{|c|c|c|c|c|c|c|c|c|}
\hline \multirow{2}{*}{$\mathrm{NO}$} & \multirow{2}{*}{ Derajat } & $\begin{array}{l}\text { Perubahan/ } \\
\text { penurunan } \\
\text { skor/skala }\end{array}$ & $\begin{array}{c}\text { Skor/ skala } \\
\text { kecemasan sama/ }\end{array}$ & \multicolumn{4}{|c|}{ Total } & \multirow{2}{*}{$\%$} \\
\hline & & \multicolumn{2}{|r|}{$\mathrm{n}$} & $\%$ & $\mathrm{n}$ & $\%$ & & \\
\hline 1 & Fisiologis & \multicolumn{2}{|r|}{4} & 15,2 & 1 & 3,8 & 5 & 19 \\
\hline 2 & $\begin{array}{l}\text { Oversensitiv } \\
\text { ity }\end{array}$ & \multicolumn{2}{|r|}{13} & 47,71 & 2 & 7,34 & 15 & 55 \\
\hline \multirow[t]{3}{*}{3} & $\begin{array}{l}\text { Concentrati } \\
\text { on Anxiety }\end{array}$ & \multirow{2}{*}{\multicolumn{2}{|c|}{3}} & 11,13 & 4 & 14,48 & 7 & 26 \\
\hline & & & & 74 & 7 & 26 & 27 & 100 \\
\hline & Uji Wilcoxon & \multicolumn{2}{|l|}{$=0000$} & & & & & \\
\hline
\end{tabular}

Berdasarkan tabel diatas, responden dengan derajat kecemasan fisiologis setelah diberikan terapi bermain didapatkan 4 responden mengalami perubahan skor/skala kecemasan dan 1 orang skor/skalanya sama/tetap, untuk responden yang mengalami oversensitivity setelah diberikan terapi bermain didapatkan 13 orang mengalami perubahan/penurunan skor/skala dan 2 orang tidak, sedangkan untuk concentration anxiety setelah diberikan terapi bermain didapatkan 3 orang yang mengalami perubahan skor/skala dan 4 orang skor/skala kecemasan tetap/sama. Berdasarkan uji Wilcoxon diperoleh hasil $(p=0,000)$ dimana ada pengaruh derajat kecemasan anak sebelum dan sesudah terapi bermain.

\section{Pembahasan}

\section{Kecemasan sebelum terapi bermain}

Berdasarkan tabel 4 dapat diketahui bahwa derajat kecemasan pada anak sebelum diberikan terapi bermain terbanyak yaitu Oversensitivity 55\% (15 orang). Kecemasan adalah sebagai respon individu terhadap suatu keadaan yang tidak menyenangkan dan dialami oleh semua makhluk hidup dalam kehidupan sehari-hari (Suliswati, 2005). Menurut Wong (2008), bermain merupakan media yang baik untuk belajar karena dengan bermain anak-anak akan berkata-kata (berkomunikasi), belajar menyesuaikan diri dengan lingkungan, melakukan apa yang dapat dilakukannya, dan mengenal waktu, jarak serta suara. Respon psikologi kecemasan diantaranya adalah gelisah, gugup, tegang, khawatir, waspada, merasa bersalah atau malu (Struart, 2002). Pada anak yang menjalani hospitalisasi, seringkali kebutuhan untuk mengekspresikan sikap permusuhan, marah atau perasaan negatif lainnya muncul dengan cara lain seperti irritabilitas dan agresi terhadap orang tua, menarik diri dari petugas kesehatan, tidak mampu berhubungan dengan teman sebaya, menolak sibling atau masalah perilaku sekolah. Kecemasan yang terjadi pada anak saat menjalani hospitalisasi dapat memperlambat proses penyembuhan, menurunkan semangat untuk sembuh dan tidak kooperatif terhadap tindakan yang diberikan oleh petugas kesehatan sehingga akan mempercepat terjadinya komplikasi selama perawatan.

Berdasarkan tabel 4 dapat diketahui bahwa derajat kecemasan Fisiologis pada anak sebelum diberikan terapi yaitu 19\% (5 orang). Menurut Stuart dan Sundeen (1998) kecemasan berkaitan dengan perasaan ketidakpastian dan ketidakberdayaan, pada keadaan cemas dan seseorang cenderung memusatkan perhatian pada hal lain atau mengesampingkan suatu hal. Menurut Landreth (2001) terapi bermain adalah salah satu saran yang digunakan dalam membantu anak mengatasi masalahnya sebab bagi anak bermain adalah simbol verbalisasi. Respon fisiologis kecemasan anak akibat perpisahan akan menunjukkan sakit perut, sakit kepala, mual, muntah, gelisah, sulit berkonsentrasi dan mudah marah (King \& Bernstein, 2001 dalam Pot \& Modleco 2007). Penelitian lain oleh Harrel (2003) memperkuat bahwa tindakan-tindakan keperawatan medis yang dilakukan akan lebih mudah diterima jika 
dilakukan secara terapeutik dan anak telah melalui adaptasi dengan lingkungannya. Permainan yang terapeutik akan dapat meningkatkan kemampuan anak untuk mempunyai tingkah laku yang positif. Selain itu permainan terapeutik sesuai perkembangan anak dapat memperbaiki gangguan emosional dan mengatasi kondisi fisik anak. Ketakutan anak terhadap perlukaan muncul karena anak menganggap tindakan dan prosedurnya mengancam integritas tubuhnya. Hal ini menimbulkan reaksi agresif dengan marah, berontak, ekspresi verbal dengan mengucapkan katakata marah, tidak mau bekerja sama dengan perawat dan ketergantungan pada orang tua.

Berdasarkan tabel 4 dapat diketahui bahwa derajat kecemasan Concentration Anxiety pada anak sebelum diberikan terapi yaitu 26\% (7 orang). Respon emosional dari stres anak dapat disebabkan karena perpisahan, lingkungan asing dan prosedur yang menyakitkan (Li \& Lopez, 2006). Stres dan kecemasan anak yang menjalani hospitalisasi dipengaruhi oleh karakteristik personal anak, yang meliputi umur, jenis kelamin, budaya, pengalaman hospitalisasi, dan pengalaman medis sebelumnya. Anak yang menjalani hospitalisasi dapat bereaksi terhadap perpisahan dengan menunjukkan kesendirian, kebosanan, isolasi dan depresi (Muscari, 2001). Perawatan anak di rumah sakit memaksa anak untuk berpisah dengan lingkungan yang dicintainya, yaitu keluarga dan terutama kelompok sosialnya dan menimbulkan kecemasan. Perawatan di rumah sakit juga membuat anak kehilangan kontrol terhadap dirinya.Perawatan di rumah sakit yang mengharuskan adanya pembatasan aktivitas anak sehingga anak merasa kehilangan kekuatan diri.Perawatan di rumah sakit sering dipersepsikan oleh anak sebagai hukuman sehingga anak merasa malu, bersalah, atau takut.

Berdasarkan tabel 1 dapat diketahui bahwa sebagian besar responden berjenis kelamin laki-laki yaitu 18 orang $(67 \%)$ mengalami kecemasan dibandingkan perempuan yaitu 9 orang $(33 \%)$. Reaksi anak terhadap hospitalisasi dipengaruhi oleh faktor jenis kelamin (Hockenbery \& Wilson, 2009). Penelitian oleh Battrick and Glasper (2004) memperkuat bahwa anak laki-laki memiliki ketahanan yang lebih besar terhadap adaptasi. Menurut Monks Knoers, dan Rahayu (2006), anak usia sekolah (6-7 tahun) mengalami kecemasan dan kecakapan verbal lebih banyak pada anak perempuan, kecakapan pengamatan ruang dan kecakapan kuantitatif lebih banyak pada laki-laki.Dari hasil diatas dapat disimpulkan bahwa anak laki-laki lebih mudah mengalami kecemasan dibandingkan dengan anak perempuan.

Berdasarkan tabel 2 diketahui bahwa sebagian besar responden yang belum pernah dirawat di rumah sakit yaitu 19 orang $(70 \%)$ dibandingkan dengan responden yang sudah pernah dirawat di rumah sakit yaitu terbanyak 8 orang $(29 \%)$. Pada penelitian ini responden yang belum pernah dirawat lebih banyak dibandingkan dengan responden yang sudah pernah dirawat. Penelitian lain menyebutkan bahwa anak yang memiliki pengalaman menjalani hospitalisasi memiliki tingkat kecemasan lebih rendah dibanding pada anak yang belum pernah memiliki pengalaman hospitalisasi (Tsai, 2007). Pada anak yang memiliki pengalaman hospitalisasi lebih mudah beradaptasi dengan lingkungan di rumah sakit dan juga tindakan keperawatan yang akan didapatkan.Anak yang pernah dirawat di rumah sakit akan merasa lebih terbiasa dibandingkan dengan yang baru pertama kali dirawat. Tetapi tidak semua anak yang sudah pernah dirawat tidak mengalami kecemasan.Hal ini dapat disebabkan oleh beberapa hal seperti cara tenaga kesehatan melakukan pendekatan, sikap perawat pada saat anak mendapatkan tindakan atau prosedur medis. Jika pengalaman pernah dirawat yang lalu buruk maka anak justru akan mengalami kecemasan yang lebih buruk bila dibandingkan dengan anak yang baru pertama dirawat. Dimana pada anak yang menjalani hospitalisasi di Ruang Mirah Delima Rumah Sakit William Booth Surabaya banyak mengalami kecemasan hal ini dikarenakan baik itu dari pengalaman responden yang sudah pernah atau belum pernah di rawat dan dimana kita ketahui bahwa ruangan juga tidak menyediakan saran atau alat bermain untuk anak saat mengalami hospitalisasi.

\section{Kecemasan sesudah terapi bermain}

Berdasarkan tabel 5 didapatkan setelah diberikan terapi bermain didapatkan 4 
responden mengalami perubahan skor/skala kecemasan dan 1 orang skor/skalanya sama/tetap, untuk responden yang mengalami oversensitivity setelah diberikan terapi bermain didapatkan 13 orang mengalami perubahan/penurunan skor/skala dan 2 orang tidak, sedangkan untuk concentration anxiety setelah diberikan terapi bermain didapatkan 3 orang yang mengalami perubahan skor/skala dan 4 orang skor/skala kecemasan tetap/sama. Keadaan ini menunjukan bahwa ada pengaruh penurunan kecemasan pada anak setelah diberikan terapi bermain (mewarnai). Hal ini diperkuat oleh pendapat Supartini (2004) bahwa terapi bermain dapat mengurangi dampak hospitalisasi pada anak, permainan yang terapeutik didasari oleh pandangan bahwa bermain bagi anak merupakan aktifitas yang sehat, diperlukan untuk kelangsungan tumbuh kembang anak dan memungkinkan untuk dapat menggali, mengekspresikan perasaan atau pikiran anak, mengalihkan perasaan nyeri, dan relaksasi. Kegiatan bermain harus menjadi bagian integral dari pelayanan kesahatan anak di rumah sakit.Terapi bermain diberikan dalam upaya mengurangi cemas yang dihadapi anak akibat hospitalisasi.Dengan terapi bermain pertumbuhan dan perkembangan anak yang sakit tetap terus bisa berkambang (Alimul, 2007). Aktifitas bermain yang dilakukan oleh anak di rumah sakit dapat memberikan keuntungan sebagai berikut: meningkatkan hubungan antara klien (anak dan keluarga) dan perawat karena dengan melaksanakan kegiatan bermain perawat mempunyai kesempatan untuk membina hubungan baik dan menyenangkan baik dengan anak maupun keluarganya. Bermain merupakan alat komunikasi yang efektif antara perawat dan klien...Setelah diberikan terapi bermain anak lebih merasa tenang dan mau berinteraksi atau berkomunikasi dengan petugas kesehatan.

\section{Pengaruh terapi bermain sebelum dan sesudah terapi bermain}

Berdasarkan tabel 5 didapatkan setelah diberikan terapi bermain didapatkan 4 responden mengalami perubahan skor/skala kecemasan dan 1 orang skor/skalanya sama/tetap, untuk responden yang mengalami oversensitivity setelah diberikan terapi bermain didapatkan 13 orang mengalami perubahan/penurunan skor/skala dan 2 orang tidak, sedangkan untuk concentration anxiety setelah diberikan terapi bermain didapatkan 3 orang yang mengalami perubahan skor/skala dan 4 orang skor/skala kecemasan tetap/sama. Berdasarkan uji Wilcoxon diperoleh hasil $(p=0,000)$ dimana ada pengaruh derajat kecemasan anak sebelum dan sesudah terapi bermain. Hal ini didukung oleh penelitian Subardiah (2009) yang menunjukkan bahwa permainan terapeutik mampu menurunkan kecemasan.Melalui kegiatan bermain anak dapat memperoleh kesenangan (Hurlock, 1991; Foster, 1998; Whaley \& Wong, 1991). Kesenangan yang diperoleh anak ini terbukti dapat menurunkan kecemasan pada anak dan dapat mempengaruhi kesiapan anak ketika dilakukan tindakan keperawatan dan memberikan kesembuhan bagi anak-anak yang mengalami gangguan emosi (Mahon, 2009).Bila anak paham tentang penyakit, perpisahan dan cidera tubuh selama anak di rawat, maka diharapkan dengan pemberian terapi bermain dapat menurunkan ancaman terhadap integritas dan kecemasan yang dialami oleh anak. Dengan berkurangnya ancaman integritas fisik maka akan mengurangi stimulasi syaraf otonom mengeluarkan adrenalin sehingga respon fisik dan psikologis kecemasan akan menurun. Untuk memberikan ketenangan dan kesenangan pada anak perawat dapat memberikan permaian terapeutik ketika melakukan tindakan keperawatan maupun dalam kontrak waktu. Terapi bermain (mewarnai) menjadi alternatif bagi rumah sakit untuk dilakukan karena disesuaikan dengan kebutuhan dan perkembangan anak. Permainan pada anak di rumah sakit tidak hanya akan memberikan rasa senang pada anak, tetapi juga akan membantu anak mengekspresikan perasaan dan pikiran cemas, takut, sedih, tegang, nyeri yang akan membuat anak lebih kooperatif terhadap tindakan keperawatan yang diberikan, maka anak menjadi lebih nyaman sehingga dapat mengurangi lama rawat di rumah sakit dan dapat mempercepat proses penyembuhan.

\section{Simpulan dan Saran}

Berdasarkan hasil penelitian dan analisis diatas dapat disimpulkan bahwa 1) Sebagian besar responden mengalami derajat kecemasan Oversensitivity yaitu15 orang $(55 \%), 2)$ Sebagian besar responden 
mengalami penurunan/perubahan skor/skala derajat kecemasan Oversensitivity yaitu13 orang $(65 \%), 3)$ Berdasarkan Uji Wilcoxon didapatkan hasil signifikan sebesar 0,000, terdapat pengaruh terapi bermain terhadap kecemasan anak yang mengalami hospitalisasi di Ruang Mirah Delima Rumah Sakit William Booth Surabaya. Sehingga, beberapa hal yang dapat disarankan antara lain 1) memberi masukan kepada rumah sakit untuk dapat menyusun program terapi bermain selama anak dirawat, memberi masukan untuk institusi pendidikan dalam pengembangan materi khususnya keperawatan anak, dan untuk peneliti selanjutnya dapat digunakan sebagai acuan dalam penelitian lanjutan terkait terapi bermain pada anak sakit.

\section{Daftar Pustaka}

Adriana, Dian.2011. Tumbuh Kembang dan Terapi Bermain pada Anak.Jakarta: Salemba Medika

Alfiyanty, N. 2010. Upaya Meningkatkan Daya Pikir Anak Melalui Permainan Edukatif.

http://etd.eprints.ums.ac.id/9837/1/A520 085042.pdf diakses tanggal 13 Nopember 2013

Apriliawati Anita.2011. Pengaruh Bibloterapi Terhadap Tingkat Kecemasan Anak Usia Sekolah yang Menjalani Hospitalisasi di Rumah Sakit Islam Jakarta.Fakultas Ilmu Keperawatan Universitas Indonesia

Arikunto, Suharsimi.2006. Prosedur Penelitian Suatu Pendekatan Praktik. Jakarta: Rineka Cipta

Aziz Alimul. 2007.Riset Keperawatan dan Teknik Penulisan Ilmiah.Jakarta: Salemba Medika

Budi Anna Keliat, dkk.2011.Manajemen Kasus Gangguan Jiwa:CMHN (Intermediate course).Jakarta :EGC

Brockopp, Dorothy, dkk.1999. Dasar-Dasar Riset Keperawatan.Jakarta:EGC

Costello.2008.Hospitalisasi Diunduh http://www.answers.com/topic/hospitali zation, tanggal 17 Oktober 2013

Donna L.Wong. 2008.Buku Ajar Keperawatan Pediatrik Vol 2. Jakarta:EGC

Harini Novita.2013. Terapi Warna Untuk Mengurangi Kecemasan. Fakultas
Psikologi Universitas Muhammadiyah Malang

Hurlock, Elizabeth B.1999. Perkembangan Anak.Jakarta:Erlangga

Li \& Lopez.2006. Assessing Children's Emotional Responses to Surgery. Diunduh dari hub.hku.hk/bitstream/10722/48646/1/13 1669.pdf, pada tanggal 17 Oktober 2013

McGuire, Leah A.2013. A Comparative Analysis of the Resived Children's Manifest Anxiety Scale Scores of Traumatized Youth With and Without PTSD Relative to Non-Traumatized Controls.Columbia University

Naviati Elsa.2011. Hubungan Dukungan Perawat Dengan Tingkat Kecemasan Orang Tua di Ruang Rawat Anak RSAB Harapan Kita Jakarta.Fakultas Ilmu Keperawatan Universitas Indonesia

Notoatmodjo,Soekidjo.2005.Metodologi Penelitian Kesehatan.Jakarta: Rineka Cipta

Nursalam.2003. Konsep dan Penerapan Merodologi Penelitian Ilmu Keperawatan: Pedoman Skripsi, Tesis dan Instrumen Penelitian Keperawatan. Jakarta: Salemba Medika

Nursalam,dkk. 2005. Asuhan Keperawatan Bayi dan Anak .Jakarta : Salemba Medika

Purwandari,H.2009. Pengaruh Terapi Senu untuk Menurunkan Tingkat Kecemasan Anak Usia Sekolah yang Menjalani Hospitalisasi di Wilayah Kabupaten Banyumas. Tesis. Universitas Indonesia

Riyadi Sujino \& Sukarmin. 2009. Asuhan Keperawatan Pada Anak. Yogyakarta : Graha Mulia

Saryono.2010. Kumpulan Instrumen Penelitian Kesehatan. Yogyakarta: Mulia Medika

Sasroasmoro \& Ismael. 2010. Dasar-dasar Metodoligi Penelitian. Jakarta: Sagung Seto

Soetjiningsih.1995.Tumbuh Kembang Anak.Jakarta: EGC

Solikhah Umi.2011.Pengaruh Therapeutic Peer Play Terhadap Kecemasan dan Kemandirian Anak Usia Sekolah Selama Hospitalisasi di Rumah Sakit Wilayah Banyumas.Fakultas Ilmu Keperawatan Universitas Indonesia

Struart \& Sundeen.2002.Buku Saku Keperawatan Jiwa. Jakarta:EGC 
Subardiah,LP.2009.Pengaruh Permainan Terapeutik Terhadap Kecemasan, Kehilangan Kontrol, dan Ketakutan Anak Prasekolah Selama Dirawat di RSUD Dr.H.Abdul Moeloek Propinsi Lampung. Fakultas Ilmu Keperawatan Universitas Indonesia

Sugiyono.2010.Metode Penelitian Kuantitatif Kualitatif. Bandung: Alfabeta

Sukoati ,Suci.2012. Aktivitas Bermain Mewarnai Dapat Meningkatkan Mekanisme Koping Adaptif Saat Menghadapi Stress Hospitalisasi Pada Anak. Jurnal STIKES RS Baptis Kediri. Vol.5, No2

Supartini, Yupi. 2004. Buku Ajar Konsep Dasar Keperawatan Anak. Jakarta:EGC Theofanidis.2006.Chronic Illness in Childhood: Psychosocial Adaptation and Nursing Support for the Child and Family. Issue 2 Health Science Journal. Diunduh

http://www.hsj.gr/volume1/issue2/isseu0 2 rev01.pdf tanggal, 17 Oktober 2013

Yamin, Sofyan dan Kurniawan Heri. SPSS Complete: Teknik Analisis Terlengkap dengan Software SPPS.Jakarta: Salemba Medika

Zellawati Alice.2011. Terapi Bermain Untuk Mengatasi Permasalahan Pada Anak. Fakultas Psikologi Universitas AKI 